\title{
Introduction. International Criminal Law (ICL), International Criminal Justice (ICJ), and Public International Law (PIL): The Demarcation Debate
}

More authors were invited, and had in fact accepted an invitation to submit a contribution to what was originally planned as a double volume of this special issue - 'International Criminal Law (ICL), International Criminal Justice (ICJ), and Public International Law (PIL): The Demarcation Debate' - than the actual number of published articles reflects. In total, eight authors from six different countries (The Netherlands, USA, Singapore, West Bank, Sweden, and Colombia) secured a successful submission of individual or joint research articles to this issue. The COVID-19 pandemic, the current global health crisis that has caused so many interruptions in so many areas of human activity, is partly to blame. However, serious scholars and researchers know better than to conflate the quantitative and qualitative. This is particularly true for a theme that requires a rather comprehensive expertise. After all, 'International Criminal Law (ICL), International Criminal Justice (ICJ), and Public International Law (PIL): The Demarcation Debate' not only cuts across the various branches of international law; it also requires an interdisciplinary skillset. This single special issue alone suffices to prove that participants in the demarcation debate frequently resort to tools from such disciplines as political science, ethics, and philosophy.

Certainly, the more analytically subtle the demarcation debate becomes, the stronger the law and philosophy synthesis will manifest itself. Authors do not always declare their affiliations, especially if they are working on a concrete subject matter, challenge, or issue. Notwithstanding, their response to the demarcation debate depends more or less tacitly on one or more anchor positions or general premises which, in turn, help to clarify the definition of central concepts. For example, if ICJ is defined in terms of 'the aggregate of national jurisdictions applying international criminal law and/or internationalized criminal courts and tribunals,', there may be no room for a broader

1 Fabricio Guariglia, 'COvid-19 Symposium: Covid-19 and International Criminal Law', Opinio Juris (4 April 2020), p. 5, https://opiniojuris.org/2020/04/o4/covid-19-symposium-covid19-and-international-criminal-law/, accessed 30 June 2020. 
conceptualisation that captures those perspectives that do not fall under the set of 'legal-logical' considerations, namely, political, moral, cultural, and similar types of influence. ${ }^{2}$ That said, a seemingly non-controversial approach, one that aims to connect ICL as well as ICJ in the prevailing perception, is not necessarily inconsistent with an idealistic attempt to affect their future development; and perhaps in a direction that may reintroduce (the need for) the demarcation debate in the context of PIL.

Certainly, this seems to apply to the Director of Prosecutions for the International Criminal Court (ICC) Fabricio Guariglia's intriguing 2020 statement in Opinio Juris on the relevancy of ICL and ICJ at a point in time where the state of affairs as we know it is being transformed by the coronavirus. ${ }^{3}$ The COVID-19 crisis, the global pandemic, as he points out, raises new questions about the prevention of and response to public health emergencies in spite of the fact that 'many will advance a negative answer' to the idea(l) that ICL and ICJ (should) have a role to play. Guariglia does not dismiss the sceptics, and he therefore qualifies his own approach. More precisely, he suggests that if viewed through the correct lens 'a clear and direct connection between international crimes and epidemics' arguably results. Hereafter, Guariglia demarcates the international and national levels whereupon he deems it possible to connect 'basic truths' underlying the Covid-19 pandemic, inter alia, interdependency in terms of global security, with broad and mutually reinforcing crime causalities that introduce open variables for the order of the crimes themselves. The fact - as he sees it - is that 'epidemics and international crimes, more often than not, feed from the same toxic elements: systemic poverty, lack of education, of basic services, of state protection, of respect for individual rights, including the most basic socio-economic rights.' ${ }^{4}$ Consequently, his statement is accompanied by a 're-think' call for initiatives to develop the current crime typology and, furthermore, match this effort for the substantive aspect (e.g., in terms of international environmental crimes) with procedural analogies, i.e., new ways to secure accountability in circumstances that are convenient for perpetrators of war crimes and crimes against humanity. ${ }^{5}$ As it happens, the relevant perpetrators benefit from their own obstructions to humanitarian assistance and/or the (more or less deliberate) failure to contain deadly diseases, thereby adding to the victimization and, eo ipso, the overall accumulative harm factor. The latter is to say that the effort is not just about ending impunity and,

2 Alf Ross, Om ret og reetfcerdighed: En indførelse i den analytiske retsfilosofi (Nyt Nordisk Forlag, Copenhagen, 1966 [1953]), p. 99.

3 Guariglia, supra note 1.

4 Ibid., p. 4.

5 Ibid., p. 5 . 
if the perpetrators are in powerful positions, realpolitik; it is also about 'values and principles', first and foremost, about protection of humanity. ${ }^{6}$

This example, which draws on findings from a situation we are all still living through, is enough to show that the demarcation debate is happening right here and now because of the CoviD-19 pandemic; and that downplaying its significance and impact would amount to a blatant denial of reality. Law's boundaries are in flux. Omissions and commissions from the coronavirus crisis have sent signals to the very nucleus of international law viewed as a web - to the pillars of integration and legality. ${ }^{7}$ Obviously, the closer the pillar constellation (of integration and legality) is, the more the (emerging) law will assume the characteristics of hybrid law, of law that cuts across the various branches of PIL.

Thoughts about the ICL as an embryonic phenomenon can co-exist with ideas about its dynamic evolution, together with reasonable complaints about a demand-and-supply gap for ICJ; and (traditionally) it is legal doctrine that determines the exact 'web coordinates' for the empirical and evaluative.

Controversies pertaining to integration and legality may affect basic rights. Furthermore, the debate may go so deep as to translate the evaluative into the ethical. One example is provided by Anja Matwijkiw's article 'The Dangers of the Obvious but Often Disregarded Details in the International Criminal Law Demarcation Debate: Norm-Integration and the Triple-Thesis "Argument". This introduces analytical prevention strategies for taking too much for granted in the demarcation debate of ICL and ICJ and of the various branches of PIL: ICL, international humanitarian law (IHL), and international human rights law (IHRL). The author homes in on outlooks that are informed by different types of practice and but which all emphasize human rights that arguably correspond with or to jus cogens norms. However basic from the point of view of global and public interests, different outcomes for 'affirmative' ( $c f$. social/economic) rights result. At the same time, the view called economic realism unites theorists who otherwise are so progressive as to suggest that broad stakes in basic rights constitute a 'singular' notion of PIL and advocates of conservative ideas. Consequently, doctrinal outlooks often have no positive spill-over effects for norms that are comparatively neglected despite their bridge potential for humanity-centric crime initiatives - like those that Guariglia mentions ( $c f$. environmental crimes). Outlooks may even cast out the (too)

6 Ibid., p. 6; M. Cherif Bassiouni (ed.), Introduction to International Criminal Law: Second Revised Edition (Martinus Nijhoff Publishers, Brill, Leiden, 2012), p. 926 (for the definition of realpolitik as 'the political realist view of power's precedence over legal legitimacy').

7 See generally Giuliana Ziccardi Capaldo, The Pillars of Global Law (Routledge, Taylor \& Francis, London, 2016 [2008]). 
untraditional with an auxiliary notion of what is appropriate. Philosophicallyanalytically, Matwijkiw undertakes a similar exercise to that of peeling an onion. In particular, she demonstrates how the so-called separation thesis (for law and morality), the logical correlativity thesis for rights and corresponding duties and the interest-incompatibility thesis work together ( $c f$. triple-thesis) and give rise to a circular 'argument' - which is not a valid argument of course.

It was not this guest editor's intention to be immodest when she began the introduction of the authors to 'International Criminal Law (ICL), International Criminal Justice (ICJ), and Public International Law (PIL): The Demarcation Debate' with her own article. The reason for taking this step owes simply to the relevant article's specific attempt to uncover bias. Unless 'arrested', bias will automatically block new initiatives, in particular those with a value-holistic (rights-)scope. Setting aside the formal prerequisites for recognition, talk about crimes like ecocide may not 'rock the boat' that much provided it is true that jus cogens and the ethical domain merge. Be that as it may, legal interpretation is very much a matter of the current comfort zone. Since scholars and researchers in international law tend to be those who make discoveries, compare the past to the present and re-think everything with a view to asking questions about the future, they may unnerve the 'sitting opinion' for that reason alone.

However, in the case of Herman van der Wilt (Professor of International Criminal Law, University of Amsterdam), one exception may perhaps have been made. In 'State Practice as Element of Customary International Law: A White Knight in International Criminal Law?', Professor van der Wilt's discoveries follow in the wake of almost archaeological-analytical findings (despite his own modest statement to the contrary), that therefore go deep - to reveal the impact of a particular development on the process of identification of customary international law by international criminal tribunals and courts. More precisely, he finds that opinio juris and state practice are doctrinally obfuscated, and 'with opinio juris overshadowing state practice, at least as understood in the traditional sense' because the scarcity of inter-state practice in the area of human rights and international criminal law has led tribunals and courts to turn to legal artefacts, viz., domestic legislation and case law of national courts. Instead of brandishing the red card, though, van der Wilt reflects further and deeper still - until he finds a way in which to accommodate the peculiar phenomenon ( $c f$. identification process), thereby aligning the development 'properly' with international law. In terms of the demarcation debate, the author's examples, examinations and evaluations essentially restores law's dynamic character, just as legal practitioners and professionals become equipped with a guide for jurisprudential methodology. 
In van der Wilt's cutting-edge research, conceptual analysis and experimental philosophy go hand in hand. This does not entail a naïve optimism regarding 'shared concepts of criminal law'. The distinction between the various elements of customary international law has not only been resolved in favour of one category; it has also reshaped state practice within the sub-sections of international law. In turn, this implies both the 'unwholesome message that the way a state treats its own nationals is (still) its own business' and (continued) competition about 'the general concepts and legal institutions common to all the major legal systems of the world'. In the absence of a communis opinio of the international community on this issue, the lex certa principle (of ICL) may eventually become an open-ended variable.

The political anti-globalisation trend in Europe, driven by ideologies like neo-nationalism, ${ }^{8}$ is just one example of a push for our way rather than what is 'common to all'. This has manifested itself in an increased interest in national identity, culture, and values; and domestic laws such as the so-called burqa bans that have been introduced in a number of countries to reflect that same interest. In 2014 and 2017, respectively, the European Court of Justice (ECtHR) upheld the ban in the case of France and Belgium (cf.S.A.S. v. France, Belkacemi) Oussar v. Belgium, and Dakir v. Belgium). Other countries like Denmark went on to copy the criminalisation strategy ( $c f . \S 134 \mathrm{c}$. of the amended Danish penal code) - instead of considering the United Nations Human Rights Commission's (UNHRC) 2018 finding: that the ban violates the (universal) human rights of Muslim women. ${ }^{9}$

Admittedly, national(ist) burqa bans do not fall under international core crimes, as is the case with violations of jus cogens norms. However, they are not trivial issues, especially since contradictory judgements were rendered. Why?

8 Andre Gingrich and Marcus Banks (eds.), Neo-Nationalism in Europe and Beyond: Perspectives from Social Anthropology (Berghahn Books, New York, 2006); Eirikur Bergmann, Neo-Nationalism: The Rise of Nativist Populism (Palgrave Macmillan, London, 2020).

9 In 2018, the United Nations Human Rights Committee (UNHRC) rejected France's 'living together' justification ( $c f$. vivre ensemble) to limit universal human rights ( $c f$. freedom and nondiscrimination) as an element of the 'rights and freedoms of others', which had otherwise been upheld by the ECtHR's 2014 ruling ( $c f$. S.A.S. v. France). See un HrC, Hebbadj v. France, Communication No. 2807/2016, Views of 17 July 2018, UN Doc. CCPR/C/123/D/2807/2016; and Yaker v. France, Communication No. 2747/2016, Views of 17 July 2018, UN Doc. $\mathrm{CCPR} / \mathrm{C} / 123 / \mathrm{D} / 2807 / 2016$; ICC PR, arts. 18 and 26; ECtHR, Case of S.A.S. v. France, Application no. 43835/11, Grand Chamber, Judgment of 1 July 2014; ECtHR, Belkacemi and Oussar v. Belgium, Application No. 37798/13, Judgment of 11 July 2017; ECtHR, Fouzia Dakir v. Belgium, Application No. 4619/12, Judgment of 11 July 2017. 
Because the UNHRC does not apply the ECtHR's 'margin of appreciation' doctrine, which gives European States latitude in balancing individual rights against State interests. However, if van der Wilt's observation of 'a quagmire of law and politics' has to be accommodated, there is at least one learning lesson to be derived about the precariousness of the whole equation called law: that the troubleshooting proposal to adopt the approach that 'rules are conductrelated while principles are value-related' is insufficient. And van der Wilt abstains, although sympathetic to the proposal.

As a special issue, 'International Criminal Law (ICL), International Criminal Justice (ICJ), and Public International Law (PIL): The Demarcation Debate' also encompasses other excellent contributions that attempt to tackle the more difficult and subtle challenges having to do with sources, state practice and opinio juris in the context of ICL, PIL, general international law, and customary international law. Like van der Wilt, Diego Germán Mejía-Lemos (PostDoctoral Fellow, National University of Singapore) balances the theoretical and the practical. Mejía-Lemos's article, 'Custom in General International Law and International Criminal Law: A Survey of Selected Issues', contains an account of decisions of international criminal courts and tribunals, with a particular focus on but not exclusively confined to those of the ICTY. Furthermore, the survey - which is as comprehensive as it is engaging - incorporates a discussion of relevant works of institutions like the International Law Association (ILA) and the International Law Commission (ILC), including reports of the ILC Special Rapporteur. One main objective is to try to establish to what extent views previously identified mostly by reference to the academic literature examining various issues regarding custom are or are not 'borne out' by the surveyed decisions. On Mejía-Lemos' premises for analysis, decisions are not classified merely as parts of a mapping exercise. If and when the decisions depart from well-established positions in general international law, they are subjected to a critical appraisal.

The theoretical exploration of custom is broad and detailed. It spans the nature of custom, custom as a source of law, challenges to custom's suitability in ICL, and the possible implication of the 'two-element approach', namely, that international criminal courts resort to a form of suigeneris custom. If true, the outcome translates into an instance of judge-made law. In the process of assessing whether further qualifications of the central concept (of custom) are needed, inter alia, with the help of Jeremy Bentham's distinction between custom in foro and in pays Mejía-Lemos throws new light on the demarcation debate. His own optics, viz., that a 'bi-elemental structure' and a 'bi-directional interaction' can be ascertained (albeit 'contrary to common assumptions'), suggests that rather than causing fragmentation, international criminal courts 
and tribunals uphold the unity of international law. Undoubtedly, MejíaLemos's article is going to inspire further reflection and discussion among scholars and practitioners; and this quality is exactly the kind of impact that 'Criminal Law (ICL), International Criminal Justice (ICJ), and Public International Law (PIL): The Demarcation Debate' seeks. The ramifications may be wider and deeper than first assumed, depending on the criteria that are used for analysis and assessment.

Inspired by Cervell Hortal's 'no derogation' position on ius cogens norms, Héctor Olasolo, Juan Ramón Martínez Vargas and Laura Quijano Ortiz (Professors from El Rosario University, Colombo) ask the pertinent question, 'why should ICL ius cogens norms regulating ius cogens crimes not prevail over the PIL customary procedural rule on personal immunity, which does not have ius cogens nature?' As the very title of the three authors' joint research contribution suggests - "The Tension between State Duties to Investigate and Prosecute ius cogens Crimes and Immunity of the Highest State Representatives from Foreign Criminal Jurisdiction'- the demarcation debate aims for a particular outcome, viz., clearer separation lines, thereby limiting the overlapping circle area in what one could call the Venn diagram for ICL and IPL.

For Olasolo, Vargas, and Ortiz, both personal and functional immunity are at stake in the main example of the (demarcation) problem between (i) the state duties, under ICL, to investigate and prosecute ius cogens crimes, even if committed by foreign state officials (in particular, by the highest representatives of a foreign state) and (ii) the immunity of the latter from foreign criminal jurisdiction under customary PIL, which covers, (a) all conduct regardless of their official or private nature (personal or ratione personae immunity) while they are in office and, (b) after they leave office, all official activities that heads of state, heads of government and foreign affairs ministers have carried out while they were in office on behalf of the state (functional or ratione materiae immunity).

As advocates of 'a stricto sensu definition of ICL', the authors are as jurisprudentially activist in their argumentation as they are unapologetic about prescribing the curative measure for 'the best evidence of the 'carcinogenic pollution of political action", i.e., the commission of ius cogens crimes by the incumbent highest representatives of foreign states. Given that realpolitik is ultimately a strategy for impunity by virtue of reproducing the status quo, there seems to be no escape from a critical response to the decision taken by, inter alia, the International Court of Justice (ICJ). According to the arrest warrant case, so the authors stress, 'any potential conflict between the ICL norms that regulate ius cogens crimes and the PIL customary rule on functional immunity should be avoided by differentiating between the substantive nature of the 
former and the procedural nature of the latter'. Besides an account of the ILC Special Rapporteur (for State Officials' Immunity from Foreign Criminal Jurisdiction) Concepción Escobar Hernández's dissent from the ICJ, as explicated in two reports from respectively 2016 and 2018, an impressive, per Mejía-Lemos' terminology and methodology, survey of case law serves to further contextualize the competing 'broad' and 'narrow' approaches to ICL. The broader the approach, the more 'tension and overlap' between ICL and PIL, to the extent that no (ius cogens) exception (to immunity) is deemed appropriate, however progressive (read: however instrumental for the promotion of 'essential values'). It follows, of course, that it is the narrow approach that coincides with the rescue measure called a stricto sensu definition of ICL.

As noted at the outset, authors who tackle a concrete subject matter may choose to, at least in one sense, (more or less tacitly) bypass the question about the more general position they are persuaded by - as if there existed a risk of digression. Such concentration and analytical attentiveness to the subject matter at hand in no way has to be at the expense of the kind of holistic and critical engagement that is also characteristic of philosophically minded legal scholars and experts. One example of this is the article written by Samuel Jake Romm (University of Pennsylvania), 'No Home In This World: The Case against John Yoo before the International Criminal Court'. Romm applies moral culpability and ethics as categories, and these are rooted in a legal doctrine that is opposed to the idea(ology) of separating law and morality. It is clear that the author is in agreement with the part of the literature whereby 'a moral case' can be made. However, Romm's main interest lies elsewhere. More precisely, he attempts to establish the prima facie case of legal culpability (against John Yoo) under the Rome Statute. Consequently, Romm's objective is to fill the gap that concerns the way that the jurisdictional issue, so far, has been hampered by the lack of state ratification.

Rather than prosecution of the principal architect of the United States Torture Program, as should be the case, the ius cogens criminality of the hostis humani generis (the enemy of all mankind) has been rewarded with de facto immunity cum impunity and success in mainstream society, including positions at law schools. In other words, former Office of Legal Counsel (OLC) lawyer Yoo and, for that matter, various other oLC lawyers and executive actors (e.g., Jay Bybee, John Ashcroft, William Haynes) have been made to 'feel at home in the world' as a consequence of the failure of U.S. courts and all other national courts - and therefore the ICC is now the forum of last resort for the purpose of correcting the justice deficit, thereby securing accountability in accordance with merit. As mentioned above, Romm prepares the grounds for the prosecution of Yoo, who 'bears the greatest responsibility' and whose 
indictment may be rendered possible by the ICC's investigation into the situation in Afghanistan. If so, the (in)famous 2001-2003 Torture Memos and Bybee Memos that Yoo authored at the OLC, authorizing members of the CIA and the U.S. military to torture detainees during interrogation at 'black sites' facilities in Afghanistan and Guantanamo Bay, will constitute evidence of the main architect's legal justifications during the Bush Administration. Waterboarding, sleep deprivation, forced nudity and stress positions are among the torture techniques that were cleared in Yoo's 'Trojan horse' strategy that 'smuggled in' criminality under the cover of legalese. By removing one obstruction after the other, inter alia, self-defence, the duress defence and the necessity defence, Romm shows that Yoo de jure must be prosecuted 'despite having perhaps the lowest profile and title of the group at the time'. Unfortunately, if the Trump administration protests 'vociferously enough', the prosecution of torture as a war crime may be further hampered. However hollow from the viewpoint of the ICC's mandate, a dissatisfied superpower counts more in the realpolitik equation.

Effective enforcement would help to fill the ICJ demand-and-supply gap, in accordance with 'the aggregate of national jurisdictions applying international criminal law and/or internationalized criminal courts and tribunals' definition of ICJ. The more the link between ethics and ICJ is invoked, the truer it becomes that values and principles (should be made to) matter and that, more generally, means not be conflated with ends. Criminal prosecution is instrumental for justice, if used properly. Pragmatism is always in the service of idealism. The same applies to law per se. Accession to or ratification of a treaty (e.g., the 1998 Rome Statute) removes formal obstacles to that particular nation state's recognition of ICL, but because jus cogens norms arguably 'are the most powerful principles we possess', it follows that '[n]o statute, treaty, or government conduct may conflict with them.'10

Article 53 of the 1969 Vienna Convention on the Law of Treaties (Vienna Convention) makes it clear that a treaty or treaty provision in conflict with jus cogens is void ab initio:

A treaty is void if, at the time of its conclusion, it conflicts with a peremptory norm of general international law. For the purposes of the present Convention, a peremptory norm of general international law is a norm accepted and recognized by the international community of states as a

10 Mary Ellen O'Connell, 'Jus Cogens: International Law's Higher Ethical Norms', in Donald E. Childress, III (ed.), The Role of Ethics in International Law (Cambridge University Press, New York, 2012), p. 80. 
whole as a norm from which no derogation is permitted and which can be modified only by a subsequent norm of general international law having the same character. ${ }^{11}$

The same is true in the case of an emerging norm ( $c f$. Article 64 of the Vienna Convention), as well as national or domestic law.

Yet other implications of the so-called legal process theory are as radical as they are potentially progressive. ${ }^{12}$ Interestingly enough, the doctrine is formulated by American legal scholars who claim that jus cogens norms belong to a special 'subcategory of general principles' that are not consent-based (such as customary or treaty law,) but instead 'integral' ( $c f$. necessary and inherent) to the legal system. ${ }^{13}$ As such, jus cogens norms constitute foundational norms. Their status as extrapositivist cum ethical norms means that they 1. operate like public policies; and 2. are 'mandatory and imperative at all times' and include the prohibitions on aggression, genocide, slavery, arbitrary killing, apartheid, and torture. ${ }^{14}$

As an 'international legal category', jus cogens norms are indisputably anchored in a non-separation of law and morality. The essential point is, however, that this does not affect the law's status as law, nor its certainty for that matter. By extension, the theory's voidance of the U.S. Torture Program and, ipso facto, American exceptionalism, can also support ICJ collective $\mathrm{R}_{2} \mathrm{P}$ guarantees that go beyond the ICC's complementarity model (in circumstances of jurisdictional stalemate) while, at the same time, appealing to 'community evidence' like the United Nations rule of law standards that set the bar as high as a zero tolerance response towards jus cogens crimes. ${ }^{15}$ If jus cogens norms were to be treated as an analogy to Hans Kelsen's basic norm, the demarcation debate would be altered in ways that would create a new reality for states as

11 United Nations, Vienna Convention on the Law of Treaties, UN Doc. A/CoNF.39/27 (23 May 1969; entry into force, 27 January 1980).

12 Basic human rights constitute an important exception. This is to say that American Legal Process Theory (ALPT) espouses a traditional and conservative view, which favors civil/ political rights. See Anja Matwijkiw and Bronik Matwijkiw, '[Human] Values and Ethics in Environmental Health Discourse and Decision-Making: The Complex Stakeholder Controversy and the Possibility of 'Win-Win' Outcomes', in Stefania Negri (ed.), Environmental Health in International and EU Law: Current Challenges and Legal Responses (RoutledgeGiappichelli Studies in Law, Turin-Abingdon, 2019), p. 17.

13 O'Connell, supra note 10, p. 84.

14 Ibid., pp. 80, 92, 97-98.

15 Ibid., p. 94. 
subjects to international law, but this introduction has to leave such a topic to the imagination of the readers.

What is more, the last author and article is bound to get everyone firmly grounded again - back on planet earth and in exactly the kind of fighting zone that leaves either little or no hope for a visionary post-Westphalian era. In 'What is Palestine? The de jure Demarcation of Boundaries for the ICc Ratione Loci and Beyond', Mutaz Qafisheh (Associate Professor, Hebron University) continues in the vein of a legal-critical account of jurisdictional and state recognition issues before the ICC, but this time around in a fashion that illustrates just how concrete and literal the demarcation debate can be - because it can be about borders, in the case of Palestine, about 'border issues'. The very same challenge also demonstrates just how connected the concrete and what M. Cherif Bassiouni treats as deep theory are. ${ }^{16}$ Furthermore, with Qafisheh's contribution, this special issue - 'International Criminal Law (ICL), International Criminal Justice (ICJ), and Public International Law (PIL): The Demarcation Debate' - comes full circle in the sense that it is written with the same holistic awareness as is found in van der Wilt's law-politics constellation, just as ethics is introduced as a variable. The fact that Qafisheh's academic expertise on the Israel-Palestine conflict and on peaceful settlement of disputes go hand in hand with practical experiences that encompass United Nations positions (e.g., the United Nations Office of the High Commissioner for Human Rights, Middle East Regional Office) is something that cannot but add a special quality to his contribution.

Thematically and generally, Qafisheh's article is concerned with the negative effects to the ICC's prosecutorial authority in the wake of 'unfixed' borders. More generally, Qafisheh sets out to dispute the premise that the Court has no competence in a State with such borders.

Therefore, Qafisheh's otherwise enthusiastic welcome of the ICC Prosecutor Fatou Bensouda's 2019 pronouncement in favour of commencing an investigation into the situation of Palestine is tempered by the fact that it (the investigation) was made conditional on a prior determination of Palestine's

16 Anja Matwijkiw and Bronik Matwijkiw, 'A Modern Perspective on International Criminal Law: Accountability as a Meta-Right', in Leila N. Sadat and Michael P. Scharf (eds.), The Theory and Practice of International Criminal Law: Essays in Honor of M. Cherif Bassiouni (Martinus Nijhoff Publishers, Leiden, 2008), pp. 19-79; Dylan Bushnell, 'Re-Thinking International Criminal Law: Re-Connecting Theory with Practice in the Search for Justice and Peace', 28 The Australian Yearbook of International Law (2009) 57-90, 67 (for 'ontologies of "humanity" as considerations that Bassiouni uses (according to Bushnell), as bridges between ICL and justice and peace). 
territory, thereby making a ruling on the scope of the Court's territorial jurisdiction a prerequisite for war crimes proceedings. Although a State Party to the 1998 Rome Statute, the ICC Prosecutor appeared to have reopened the old case of Palestine's status as a sovereign State for political reasons. Israel backed the implicit finding cum doubt, with Yehuda Blum's (politically convenient) 1968 theory against the recognition of Palestine. The recycling of this theory, which continues to be the official view of Israel, has therefore reproduced the power balance in the course of an 'exceptional' process, namely, when the ICc Prosecutor submitted her 2020 'Request to the ICC Pre-Trial Chamber I asking the Court to adjudicate on the confirmation of the scope of the territory of Palestine'.

According to Qafisheh's analysis, the question of borders is legally a nonissue. Objectively, a reference to the rules of international law suffices to provide the confirmation. The outcome of the investigation that he himself undertakes to substantiate and indeed evidence a historical conversion of de facto to de jure borders is consistent with a redundancy effect for the Request, 'beyond (and in addition to) United Nations (UN) resolutions that have been cited by the ICC Prosecutor in her Request'. Apart from an examination of the post-1948 Palestine-Israel case, a separate section is designated to the precursor involving Jordan and Egypt before 1948. ${ }^{17}$ Finally, the establishment of the ICC's ratione loci jurisdiction over Palestine's territory, which follows as a legal implication of the concrete cum de jure demarcation, is subject to 'further reaffirmation' by fifty years of State practice.

Legally, an analogy between Palestine and Afghanistan is made, just as ' $[t]$ here is no need to treat Palestine/Israel boundaries any different' than Greece, Libya, South Korea, Sudan, Turkey, and Russia. Consequently, '[t]he fact that Palestinians and Israelis are undergoing a negotiation process to fix the final boundaries between the State of Palestine and the State of Israel does not modify Palestinian territorial entitlement over the West Bank, including

17 Recently, John Quigley made the following statement: 'The occupation of the West Bank was unlawful from the outset because Jordan, then in control of the West Bank, had come to the aid of Egypt in an act of collective defense after Egypt was attacked by Israel. Israel's troop entry into the West Bank therefore was unlawful'. Quigley went on to issue a call for international action while noting that ' $[\mathrm{t}]$ he failure of the international community to deal with them has let Israel proceed from one unlawful act to another, perpetuating a conflict whose end is not in sight'. See John Quigley, 'The Annexation of Land in Occupied Palestine: Time for International Action, Opinio Juris (30 June 2020), p. 4, https:// opiniojuris.org/2020/o6/3o/the-annexation-of-land-in-occupied-palestine-time-forinternational-action/, accessed 30 June 2020. 
East Jerusalem, and Gaza Strip'. By extension, no exemption to the ICC's ratione loci jurisdiction over Palestine's territory is warranted on a 'correct legal position'. Concerning customary international law ( $c f$. state practice), treaty law plays a particular role in the reaffirmation. Any refusal to acknowledge the conclusion, that the (alleged) territorial question is already resolved and that a claim or judgment that contradicts this is tantamount to the introduction of a slippery slope for the Court's competence in relation to other ICc State Parties with disputed borders or conflicting spatial claims, including Afghanistan, $\mathrm{Cy}$ prus, Greece, Serbia and South Korea. Negative effects also seem inescapable for non-ICC parties who would face similar issues upon accession to or ratification of the Rome Statute, such as India, Pakistan, Russia, Turkey and Sudan.

The demarcation debate, whether tackled as a concrete and literal matter ( $c f$. border issues) or as a more abstract philosophical and doctrinal discussion, is one that addresses some of the most important stakes, ranging from statehood to basic human rights, and to law's own integrity ( $c f$. PIL branches and boundaries) and proper direction. The articles for 'International Criminal Law (ICL), International Criminal Justice (ICJ), and Public International Law (PIL): The Demarcation Debate' captures the complexity of the debate while responding to some of the most difficult challenges and issues; and that in itself is an accomplishment.

\section{Acknowledgments}

It has been an honour and a privilege to work with the various cutting-edge scholars of this special issue. The honor has been made even greater by the Editor-in-Chief Caroline Fournet's collaboration throughout the process. Without her valuable contributions to the various steps of the double-blind peer review process, this special issue would not have accomplished the highest standards for quality research. Finally, I wish to thank the United States Department of State's Bureau of Educational and Cultural Affairs (ECA), the American and Swedish (bi-national) Fulbright Commissions and the Institute of International Education (IIE) for selecting 'A Dual-Aspect Theory of Life, Freedom and Security: Ethics-Integration, Human Rights and Rule of Law' and 'Human Rights, Values and Legal Trends: The Role of Ethics [in Public International Law]' for the combined research and teaching award that formed the basis for my 2019-2020 position as the Fulbright U.S. Distinguished Chairp on Public International Law at the Raoul Wallenberg Institute of Human rights and Humanitarian Law \& Faculty of Law, Lund University, Sweden. This 
award and honor is also the original source of inspiration for the special issue, 'International Criminal Law (ICL), International Criminal Justice (ICJ), and Public International Law (PIL): The Demarcation Debate'. All views expressed in this special issue are solely the responsibility of the author.

\author{
Guest Editor \\ Anja Matwijkiw \\ anja.matwijkiw@rwi.lu.se;amatwijk@iu.edu
}

